\title{
DESIGNING ENGLISH TRANSLATION TOWARDS INDONESIAN MODERATE RELIGIOUS BASED SCHOOL
}

\author{
Mohammad Iskandar Dzulkurnain ${ }^{1 *}$, Sunardi $^{2}$, Siswandari $^{3}$, Asrowi $^{4}$ \\ ${ }^{1}$ Doctoral Student of Educational Science Program, Universitas Sebelas Maret, Surakarta, Indonesia; ${ }^{2,3,4}$ Lecturers of \\ Educational Science, Universitas Sebelas Maret, Surakarta, Indonesia. \\ Email: ${ }^{1 *}$ dzoel.is.kandar@ @mail.com, ${ }^{2}$ sunardi.ipuns@ staff.uns.ac.id, ${ }^{3}$ siswandari@ staff.uns.ac.id, \\ 4 asrowi@staff.uns.ac.id
}

\section{Article History: Received on $24^{\text {th }}$ March 2020, Revised on $24^{\text {th }}$ April 2020, Published on $16^{\text {th }}$ May 2020}

\begin{abstract}
Purpose of the study: The purpose of this research is to unearth English teaching, delivering and translating the holy book of instructional design in Pesantren Budi Utomo (PBU) which is the Indonesian moderate religious-based school of East Java, Indonesia in terms of kind of syllabus, learning objectives, materials instruction, evaluation, teaching designs, vigor and its debility of instructional design in English teaching.
\end{abstract}

Methodology: It is qualitative research with ethnographic design. The data conducted in this research are the intended activities in the teaching-learning process, informants, and essential documents relied on the teaching-learning process. The data is collected through observation, interviews, and documentation. The collected data are analyzed through data reduction, categorization of data, and synthesis and arrange work hypothesis.

Main Findings: The syllabus that applies as a reference for preparing lesson plans is based on the National Curriculum and the Pesantren (religious-based school) Curriculum. The learning objective includes general learning and specific learning purpose. The learning objective of English learning at PBU is in line with English for Specific Purposes (ESP). The application of curriculum is 50\% for the religious-based school curriculum and 50\% for the government curriculum. There are many instructional teaching materials such as print, audio, and visual and non-printed. Class activities are another sketch to make students spend their full attraction and attention. Evaluations are conducted periodically.

Applications of this study: The syllabus produced from this study is used by the religion-based Islamic school at the secondary level. It has a function to become a bridge for language learning to ease the students for English acquisition.

Novelty/Originality of this study: Some similar researches were done to find out more about translation but it has not found yet research that focused on creating a syllabus to facilitate the student in learning the holy book of Islam through translation.

Keywords: Curriculum Design, English Teaching, Translation, Moderate Religious School, Syllabus, ESP.

\section{INTRODUCTION}

The role of English is to make language learners easier to explore knowledge, networks, and connections. Communication between countries in the world will be intended and very involved. As the significant usage of English, the Ministry of Education of Indonesia has stated in the National Curriculum has involved implementers, scholar home representatives, and government officials who have paid attention to teaching English in its making. They support English development in Indonesian education as it becomes one of the means for communication by worldwide perspective, information, technology, and the transfer of science. The highlight of the education system is intended primarily to gather students' needs and adopt education along with the science-tech adjustment.

English is taught for the students in public schools but also in Indonesian religious school-based. It becomes the role model in religion, economic, and cultural aspects of society. As a result, it is suggested to provide useful information to their community and because of its function, English is learned there instead of Arabic. As an institution of education, it becomes a place to study religion and learn English for people. There are several distinctive features found in PBU. First, it develops students' English skills in delivering and translating the holy book by studying it in the origin language. PBU promotes to build a conducive learning environment in language acquisition. Intensive English learning is gained by the students because they have to live in a dormitory and use English as their mandatory language to communicate daily. In the evening, learning knowledge about religion, for example, studying a holy book which has been translated into English for them. It is expected that students will have other distinctive features covering experience, independent spirit, and the ability to establish the independence of employment knowledge in the language course. Religious school-based can prove that the success of English teaching through the fact that the majority of PBU graduation can become "International Religion Speaker" whose duties are abroad such as Australia, the US, Japan, and Singapore.

As an essential language from a worldwide perspective, it becomes a basic necessity to learn English. A skill must be prepared to face and welcome the future by mastering skills for their future life (Warschauer, 2000). The intention of foreign language learning is the competency to understand the connotation, natives' writing, and speech, including its 
meaning to gain achievement and ideas (Lado, et.al, 1967). From the national education perspective, English is the key to a better life for any aspect of the future (Kırkgöz, 2005).

The teachers' role will motivate students to meet with the aim of education. It is clear that attitude and achievement are the results of being reached from the learning process. It expands students' perspectives on the learning process. There are some activities done to improve the quality of the instructional process to be more active, meaningful, and interesting. It is through the curriculum that students could master after accomplishing a certain study program by formulating skills and experiences.

Related to the design of English instructional teaching at PBU, it arouses the researcher to reveal it. Instructional design components are learning objectives, class procedures, and techniques, the role of student, teacher, the teaching materials, and the media. The major purpose of providing learners with proper English skills will enable them to participate in many academic activities. (Richard \& Rodgers, 2001). Students' English learning in Gontor Religion Boarding School shows that the success of English teaching and learning in religious school-based is caused by several factors (Mahmud, 2017). First, English is used regularly as a means of communication other than Arabic. Second, English is the most important language instead of Arabic, so the learners pay the most attention to it. Third, there are many characteristics in their teaching and learning activities. It applies the direct method by saying what they know. Teachers always give their students some English vocabulary to be remembered by students every day. If there are students who break the rules, the teachers will punish them with education penalties, such as: arranging English jumbled words into correct sentences, remembering English vocabulary, taking conversations, etc. The teachers do not give physical punishment. Pondok Pesantren At-Tarbiyah Al-Religion (PPAA) religious school-based, by staying in the dormitory with English as the daily language for communication will make the students study it intensively (Hidayat, 2017). English instructional design in PPAA does not use a written syllabus, but the teachers use a timetable instead. The material source is taken from Practice and Progress, one of the New Concept English Language series by L.G Alexander. The methods used by teachers are storytelling, reading aloud, dictation and translation, discussion, questions, and answers, listening to tapes, cassettes, doing grammar and drilling exercises, games, and role-plays. Media available at PPAA are pictures, audio recorders, and realia. There is no library and laboratory.

Based on the results of preliminary studies in English teaching at religious school-based, the success of language learning is determined by the teachers in choosing topics, materials, media, and interesting methods used by students in their daily life. This is supported by the consistency of religious school-based policies in applying English in communication.

The instructional design of English teaching occurs in many aspects of instructional design. Based on the background above, the researcher is interested in analyzing the instructional design of English teaching, delivering and translating the holy book in PBU in terms of learning objectives, syllabus, learning materials, designs for teaching, assessment, and weaknesses and strengths of instructional design of teaching English. This research is held at PBU, Jombang, East Java, Indonesia.

\section{SIGNIFICANCE OF RESEARCH AND OBJECTIVES}

The significance of the research supports the idea that few kinds of literature can be found about the framework in how the teachers take the planned teaching and learning actions to a lesson (Richard \& Rodger, 2001). Because the instructional design directly influences teaching effectiveness, it is important to explain the teachers' creativity in designing teaching and learning. This information is very important to ensure quality in teaching and learning English at religious school-based. The level of method analysis in which we consider:

a) What the objectives of the method are,

b) How language content is selected and organized within the method, that is, the syllabus model the method incorporates, c) type of learning task and teaching activities the method advocates,

c) The role of the learner, e) the role of teachers and f) the role of instructional material" (Richard \& Rodgers,2001).

Therefore, the results of this study may provide an idea of how teachers can be supported in preparing instructional design to achieve learning efforts. Also, looking through the results of the study, the decision-makers will have an opinion about what instructional design that the teachers create or do not create in their daily teaching English. Therefore, they would take some initiatives in the areas teachers' creative skills need to be improved.

\section{LITERATURE REVIEW}

\section{Syllabus}

To pursue an effective learning process, it is necessary to submit the structure or chronological order of the syllabus to be specified as the main content in language teaching (Sabah, 2018). The construct of the syllabus must be set in schematically to provide teaching's reference (Widdowson, 2003). The base of types of courses in the syllabus becomes 
the statement planning of its content (Nunan, 1998). What is given in the course in the teaching-learning process in a set of significant documents is called syllabus ( $\underline{\mathrm{Ur}, 2006})$ ? Following the statement above, the certain program in language teaching to be designed is namely as syllabus (Brown, 1996).

The syllabus is categorized into some types covering; (1) Structural syllabus. It transfers the content of language on its grammatical, structures, and forms; (2) Situational syllabus is set to give real situation relied on language experimental learning theory of communicative dimension. It includes dialogue, memorization, listening, and role play. (3) The notional-functional syllabus is used to find out the language function, idea, and concept to express and recognize its communicative goal. Speaker's language used and the meaning becomes the main element to form the aim of its expression. It underlines the aspects of functional and social competence based on the language description and theory; (4)Built-in syllabus is a process where language mastery explored through internal mechanism enabling of grammar construction in limited data; (5)Proportional syllabus. It provides functional and non- functional elements by a close interweaving over time. (6)the negotiated syllabus is the key point of the problem-solving and social model where the learners practicing negotiation and role play by involving teacher and learner.; (7) procedural syllabus is graded and grouped within the tasks from their conceptual and similarity. (8)The skill-based syllabus is the content of language teaching is a collection of specific abilities that may play a part in using language; (9) content-based syllabus is the teaching of content or information in the language being learned with little or no direct or explicit effort to teach the language itself separately from the content being taught; (10) Task-based syllabus. It offers a specific realization of communicative language teaching and differs from previously proposed syllabuses like structural and functional notional syllabus; (11) Lexical syllabus. It rests that students must be able to understand and use a lexical phrase such as chunks, prefabricated patterns, and collocation; (12) Multi-dimensional syllabus. It involves shifts of focus within each teaching unit and the section of the unit focus on a structure, others on a function and stills other perhaps in a syllabus of learning procedures (Mahdi et al, 2013).

\section{Learning Goal}

The goal of the learning comes into statement reflected on skill, knowledge, and attitude. The learning goals must present its instruction as the extra supporting element instead of the resulted statements. The target that students should achieve and complete is the statement of learning goal (Simon and Taylor, 2009; Anderson et al., 2001; Harden, 2002; Kennedy et al., 2006).

\section{Instructional Material}

Instructional materials have a definition where it functions as the media to send or transfer any kind of information from teachers to learners (Amuseghan, 2007). Richards \& Rodger (2001) mentioned that language instructional processes in the classroom provide inputs of the language in the instructional material including (a) worksheet, workbooks, book, (b) computer-based material, audio material, or cassette and videos, (c) any materials from the internet.

There are some roles from the material in the teaching-learning process namely: (1) written and oral source (2) interactive communication and practice (3) source for learning language aspects (4) ideas exploration for activities in the classroom, (5) identifying determined to learn goals and (6) gaining more confidence on experienced teachers (Cunningsworth, 1995).

\section{Classroom Activities}

Individual work, group work, and in-class activity are the ways to set up a classroom series of events. It needs to know the preceded condition of a certain classroom before applying them (Chiriac \& Frykedal, 2011). It must suit the needs. Different challenges and enjoyment may result in the learning process both for the student and teacher.

\section{Media}

The environment is one of the components in learning included methodology and media as the teaching tool for education by the teacher (Sudjana, 2002). Media offers some benefits for the instructional process such as; less time consumption, energy-friendly, interactive, and supporting teachers to be positive.

\section{METHOD}

\section{Research Subject}

The research subjects of this study were teachers and students at PBU, East Java, Indonesia. Referring to the phenomena as described above, this study applied an ethnography research by some considerations involving; classroom activities, capturing the interaction between teachers and students as the grounded theory, exposing the relationship between culture and teacher- students' role. 


\section{Population and Sample}

The Population of this study was the teacher and the student's pub, East Java, Indonesia by the qualification of vocational high school level. The participants in this research were selected using purposive sampling. Purposive sampling is commonly used in qualitative research. In this case, the research only observed for XI grades of vocational high school with three classes for each of them at a religious-based class. The samples were 6 (six) teachers and 90 (ninety students).

\section{Data Collection Method}

The approach of this study is ethnographic study. Ethnographic research is one of the qualitative research strategies in which the researcher investigates a cultural group in a natural environment in a fairly a long period in the collection of primary data, observation data, and interview data to build a systematic understanding of culture from the perspective of people who have studied the culture (Creswell, 1998; Fatchan, 2015). The roles of the researcher in this research are: as a planner, as a data collector, as an analyst, and an originator of ideas. He carried out participative observation in a relatively long time and openly conducted in-depth interviews. The data used in this study are a) the intended activities in the teaching-learning process which is carried out in the classroom, b) verbal and written answers obtained from informants, the informants in the study are considered as key informants, c) the result of participative observation in a form of field notes of observation. In doing observation, the researcher culturally kept in touch with people under his research in their daily lives. In this case, the researcher chooses the informant who is considered to know the problem and can be trusted to be a data source that has deep truth and knowledge. The selection of informants uses the snowball sampling technique, which is the process of determining the informant based on the previous informant without defining the exact amount by digging up information related to the research topic. The choice of informants can develop according to the needs and stability of the researcher in obtaining data (Nugraheni, 2014: 64). Secondary data in this study were data obtained from documents that are the profile, material, learning goal, the design includes roles for the student and teacher, activity in the classroom, syllabus, teaching procedure, evaluation, and media of PBU. Several methods of data collection are often used in qualitative research, namely participatory observation, in-depth interviews, life history investigations, and document analysis ( Sugiyono, 2013).

Regarding the validity of the data, steps can be formulated by the researcher to obtain reliable data. The validity of the research data was carried out by triangulating the data. It is used to check the validity of the data, which in its sense, applying something else in comparing the results of interviews with the object of research (Moloeng, 2012). Data analysis in ethnographic research is a step forward, which is a process started by setting informants to writing ethnography (Creswell, 1998). In analyzing data, the study applies a constant comparative method (Moleong, 2012). It is initialized by reducing, categorizing, synthesizing the data for arranging the hypothesis. The important and major data was taken while less one was omitted. The coding and identifying unit took place here. Breaking the unit data is the first step of identification. The data processed was only the one that correlated with the instructional process. Coding comes to the following step. Analyzing and searching the data easily are the goals of data code delivery. To categorize the rules' version, it was done by comparing incident to incident. To find out the relation between categories to the category is done by synthesizing. In constructing the hypothesis, the researcher formulates statements proportionally. The researcher answers the research questions and problems in this study.

\section{RESULTS AND DISCUSSION}

\section{Syllabus}

English teaching syllabus in PBUis operated and designed by education level unit in the operational curriculum. It focuses on the impact and results of the students through their needs and meaningful experience. As the syllabus included in the curriculum, its design must be connected. The major difference is the scope coverage area including the aim, methodology, and evaluation as a reference to build the lesson plan is developed by English teachers in PBU. The syllabus is based on Teknik Penyusunan Silabus issued by BNSP. The kind of syllabus is classified into the national functional syllabus. It is set from the degree of difficulties from easy to complicated one.

There are three goals of English study as stated by BNSP (Education National Standard of Board) (2006) in syllabus arrangement technique namely;1) developing communicative competence written and oral to gain functional literacy, 2) realizing the significance of English in global perspective 3) meeting the understanding of culture and language for the students. The four language skill was approached by using job vacancy and any related materials to be applied in the true situation provided to do the speech in all over the world. The kind of syllabus used in PBU is the national syllabus. To accommodate the needs of second language teaching especially English, it is included in the national curriculum. The forms of words and their function are explained into the grammar. The use and notion of language are functioned as content language. The needs of the students to analyze and apply various kinds of communication and interaction are the points of notional- functional syllabus. It becomes the center to design its syllabus to expand the necessary desired.

\section{Learning Objectives}


Learning objectives of English teaching-learning in PBU is in line with English for Specific Purposes (ESP). The application of curriculum is $50 \%$ for religious school-based curriculum and $50 \%$ for government curriculum. In other words, both curriculums are applied in a balanced way.

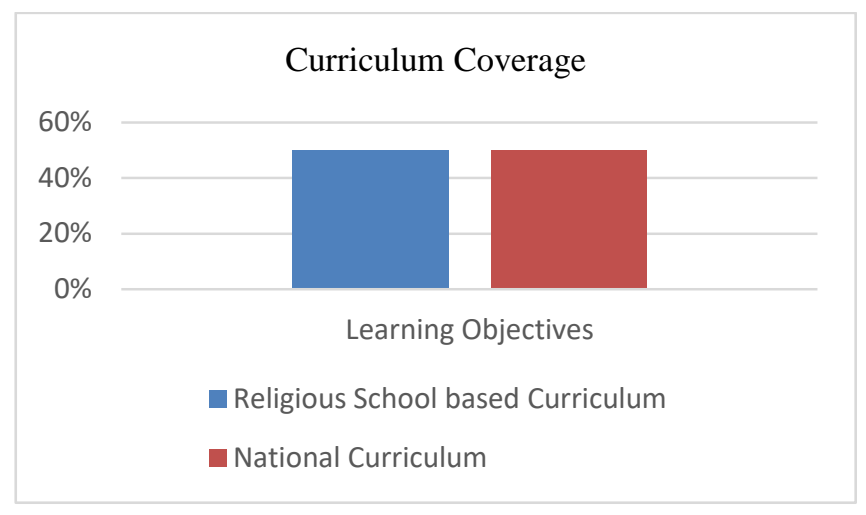

Figure 1: The Curriculum coverage at PBU

Source: (Data Process Results, 2019)

The English Language Teaching there should be selectively built and developed according to religious school based perspectives. Teachers and students and their alumny hand in hand harmonize these conflicting values for the purpose of better institutions. They strongly and carefully select the teaching materials, teaching techniques, and other classroom activities with religious perspectives. Here are some examples. The teaching materials are extra-carefully selected with religious perspectives. When they find some contradictory contents, they change them with another' sound' religious one. The leader who teaches English will insert certain expressions which do not exist in English Language Teaching materials. Another way is that the teachers try to compare ELT cultures with those of religion, meaning that this leads to learn and understand the cultures of others.

The findings above show that the learning objective encompasses two kinds namely general learning objective and specific learning objective. The general objective refers to the teaching-learning description of the curriculum for ESP. The specific learning objective is represented at a lesson plan which is stated in the indicators.

\section{Teaching-Learning Material}

PBU took different materials applied covering printed, audio, and visual material. The examples of printed materials are handouts, worksheets, magazines, etc. The goal is to push the students to learn English directly in PBU. The worksheets are paper or on the computer which involves a sheet of the question, close procedure text maps to aid the students with their exercise. The student often uses the worksheet to review what has been taught in class applied in four language skills by the teacher. The audio materials are sound recorded or produced by an electronic device. The audio is used by the teacher is the cassette, compact disk, and also flash disk in the listening section. The visual is related to something visible. It is done through the implementation of the PowerPoint office program into the learning activities. The aim is to get students' attention and feel interested in the lesson. It makes them more familiar in such a situation. The teacher compiles the materials and gives them to be mastered well. Material plays a very significant role in classroom activities by using them to set up their knowledge and capabilities. It also involves presenting, practicing, and facilitating the content independently.

Based on the explanation above, Any kind of teaching-learning aid used to assist the teacher in gaining the instructional goals with any terms of media are very useful to support meaningful classroom activities.

\section{Classroom Activities}

The results of the study show that teachers play multi-roles in PBU covering observer, controller, explainer, and organizer. They have the self-awareness to keep on motivating students to study. The main goal is to make them able to speak fluently in English. Performer, processor, and listener are some roles desired to be owned by the learners (Sadler, 1989). Three of them have been met by them as shown in their classroom participation through some activities. They discuss, listen, and do what their teacher explained to finish the task. They must remain active in keeping their role properly. The students' roles in PBUcome into a range of good category as reflected from different competence and quality among them. By comparing the other research findings, it is found that aspects form learners influence their role by considering its characteristics. The research in elementary school is cited as participant and listener, but in vocational high school has various roles. The classroom involves any roles from the teacher, student, and the classroom itself to accomplish the set goals altogether by any given materials. The way teachers set up and arrange the classroom condition 
and its activities will increase the possibility for the students to master the material well during the learning process. The teacher's responsibility is to build students' positive attitudes in the meaningful context of English learning. The teachers are successfully able to influence the students to learn enjoyably in doing the task and facing the examination. The students are also encouraged by the teacher to increase their capability through self- study, in group discussion, teacher's guidance for any obstacles found to meet the tasks. Facilitating, advising, assisting, and offering for the solution come to the teachers' role (Brown, 2000).

The classroom activities conducted in PBU having a set of series of events involving organizer, role-play, conversation, and question answer. All teachers confess that listening is the most difficult competence for the student. It demands the teacher to replay the cassette many times. After the teacher replays the cassette, the question-answer activities are done to know their obstacles in mastering the materials. Teachers do summarizing and identify some essential words to get information whole in once. The activities that support students in speaking skills are role play and reading aloud that encourage them to communicate, pronounce, and interact. It also helps the teacher to expand the classroom indefinitely and provide a natural context for the language being used. The classroom activities of the advance organizer, comprehending, answer the question, and presentation are applied in increasing writing and reading skill. The English teacher gives warming up the lesson to stimulate student attention. When teachers conduct reading comprehension, they guide the student by giving questions to make them comprehend the text. Students try to arrange their writing from the prior and or previous knowledge learned and mastered. Later, the teacher gives some guidance and revision to their writing results in the order in line with the theory. As the reflection activity, after the feedback from the teacher, they start to revise and get comments from other students in the classroom. It is done to get in closer relationships between teacher and student. It will be easy to create such enjoyable and active classroom activities in a second language learning for some barriers. It becomes the true attention of the teacher.

It is very important to establish classroom activities that promote getting their attention and attractive to study and develop the skills. It is designed to help the students' ability in language learning. The major part of the teacher's role is to set the activities that enable them to use in the functional context.

\section{Media}

It is found that the English teachers in PBU have the literacy to implement or include learning media into the classroom activities. It can be seen from how they provide them in the class to help the students to get the material effectively and efficiently. When they teach listening, they also equip cassette and compact disk to drill them in listening skills. It is obvious that media is very crucial for the teacher and student to reach the learning goals effectively. Thus, Absorbed easily by the students within the delivered material in an attractive way is called as media.

\section{Evaluation}

The English teacher of PBU gives evaluation by using the daily test, midterm test, final test, and national examination test. The evaluation is carried out periodically. The success of attaining learning objectives depends on students and teacher engagement in the classroom. The teacher at PBU implemented evaluation according to Brown's theory (2000). In short, evaluation is a device to measure the students' competences. There are three kinds of evaluation for students in Pondok PBU consisting of the periodical test in every basic competence, mid-semester after completing three-unit or more as the half elapsed topics, and final semester test as they have completed all units of the semester.

\section{CONCLUSION}

The syllabus which applies as a reference to build the lesson plan is based on National (Diknas) Curriculum and Pesantren Curriculum. The learning objective encompasses General learning objective and Specific learning objective. Learning objectives of English teaching-learning in PBU is in line with English for Specific Purposes (ESP). The application of curriculum is $50 \%$ for the pesantren curriculum and $50 \%$ for government curriculum. In other words, both curriculums are applied in a balanced way. The implementation of classroom procedure, methods applied, and literal translation type. Classroom activity is another vignette to make students spend their attractiveness and full attention. The evaluation is carried out periodically. The success of attaining learning objectives depends on students and teacher engagement in the classroom.

\section{LIMITATION AND FUTURE STUDY}

The focus of the study in this research mostly relies on the designing of a curriculum related to second language acquisition. It was done by integrating English learning through translation specialized in Islamic holy books. This study is limited only on the English mastery through curriculum design particularly on the holy book and moslem students as the samples. For future research, it is highly suggested to do related research in a wide range of matters of the subject as not only the religion one but also across subjects. The sample is recommended to heterogeneous that is not stereotyped into certain faith. 


\section{ACKNOWLEDGMENT}

We would like to say pure gratitude to the management of Budi Utomo Islamic Moderate School for the permission, support, and assistance given. Moreover, big appreciation is dedicated to the first author as taking the data, present and interpreted the qualitative data into the narrative description, second author for the valuable input in designing the ethnographic study, third author in setting, revising and validating research instruments and the fourth author for the availability to do an overall check of the final manuscript.

\section{REFERENCES}

1. Ampa, A.T. \& Rasyid, M.A. (2013). The Implementation of Multimedia Learning Materials in Teaching English Speaking Skills. International Journal of English Language Education, 1(3), 294-304. https://doi.org/10.5296/ijele.v1i3.4153

2. Amuseghan, S. A. (2007). ESL Curriculum in Secondary Schools in Nigeria: Issues and Challenges towards Communicative Competence. Nebula, 4(2), 319-333.

3. Anderson, L.W., Krathwohl, D.R., Airasian, P.W., Cruikshank, K.A., Mayer, R.E., Pintrich, P.R., Raths, J., and Wittrock, M.C. (2001). A Taxonomy for Learning, Teaching, and Assessing: A Revision of Bloom's Taxonomy of Educational Objectives. New York: Longman.

4. Brown, J. D. (1996). The Elements of Language Curriculum; A Systematic Approach to Program Development. Boston, Mass.: Heinle \& Heinle Publishers.

5. Brown, D. H. (2000). Principles of language learning \& teaching. (4th ed.). New York: Longman.

6. BSNP. (2006). Teknik Penyusunan Silabus. Jakarta: Depdiknas.

7. Chiriac, E.H. \& Frykedal, K.F. (2011). Management of Group Work as a Classroom Activity. World Journal of Education, 1(2), 1-14. https://doi.org/10.5430/wje.v1n2p3

8. Cresswel, J. W. (1998). Research design: pendekatan kualitatif, kuantitatif, dan mixed. Yogjakarta: PT Pustaka Pelajar.

9. Cunngingsworth. A. (1984). Evaluating and Selecting English Foreign Language Teaching Material. New York: MacMilan.

10. Fatchan, A. (2015). Metode Penelitian Kualitatif. Pendekatan Etnografi dan Etnometodologi untuk Penelitian Ilmu-Ilmu Sosial. Yogyakarta: Penerbit Ombak.

11. Harden, R.M. (2002). Learning outcomes and instructional objectives: is there a difference? Medical Teacher, 24(2), 151-155. https://doi.org/10.1080/0142159022020687

12. Hidaya, M. (2007). The Teaching of English at Pondok Pesantren Attarbiyah Al Religioniyyah at Paiton Ponorogo. Unpublished Thesis. The State Religious University of Malang.

13. Kennedy, D. Hyland, A., \& Ryan, N. (2006). Writing and Using Learning Outcomes: a Practical Guide. In the Bologna Handbook. Accessed Online: http://www.bologna.msmt.cz/files/learning-outcomes.pdf.(Accessed on 7 December 2019)

14. Kiraz, Hardal, Akdag \& Guzel. (2004). Designing an Instruction or Using a Designed Instruction: Critiquing the Teachers' Instructional Design Approach. Quality in Education in the Balkan Countries Conference, Sofia, Bulgaria.

15. Kırkgöz, Y. (2005). Motivation and Student Perception of Studying in an English-medium University. Journal of Language and Linguistic Studies, 1(1), 101-123.

16. Lado, R., Baldwin, B. \& Lobo, F. (1967). Massive vocabulary expansion in a foreign language beyond the basic course: the effects of stimuli, timing, and order of presentation. U.S. Department of Health, Education, and Welfare, Washington, D.C.: 5-1095.

17. Mahdi, R.N., et.al. (2013). A critical review of recent trends in second language syllabus design and curriculum development. International Journal of Research Studies in Language Learning, 2(2),63-82. https://doi.org/10.5861/ijrsll.2012.152

18. Mahmud, B. (2017). Teacher Solution to Solve the Problem in Implementing the Activities Used in Teaching Speaking English in Religious Boarding School Darussalam Gontor. The 2nd TEYLIN International Conference Proceedings,81-88. Kudus, Indonesia. ISBN:978-602-1180-45-7.

19. Moleong, L.J. (2012). Metodologi Penelitian Kualitatif. Bandung: Remaja Rosdakarya

20. Murtono. (2014). Konsep Manqul dalam Perspektif Lembaga Dakwah Religion Indonesia (LDII). Publication Script. Universitas Muhammadiyah Surakarta.

21. Nugraheni, F. (2014). Metode Penelitian Kualitatif dalam Bidang Pendidikan Bahasa. Solo: Cakrabooks.

22. Nunan, D. (1998). Syllabus Design. Oxford: Oxford University Press.

23. Richards, J.C, and Rodger, T. (2001). Approaches and Method in Language Teaching. Australia: Cambridge University Press. https://doi.org/10.1017/CBO9780511667305

24. Richards, J.C, and Rodger, T. (2001). Curriculum Development in Language Teaching. Cambridge: Cambridge University Press. https://doi.org/10.1017/CBO9780511667220 
25. Sabbah, S.S. (2018). English Language Syllabuses: Definition, Types, Design, and Selection. Arab World English Journal (AWEJ), 9(2), 127-142. https://doi.org/10.24093/awej/vol9no2.9

26. Sadler, D.R. (1989).Formative assessment and the design of instructional systems. Instructional Science,18(2), 119-144. https://doi.org/10.1007/BF00117714

27. Savery, J.R. \& Duffy, T.M. (1996). Problem Based Learning: An instructional model and its constructivist framework. In B. Wilson (Ed.). Constructivist Learning Environments: Case Studies in Instructional Design. NJ: Educational Technology Publications Englewood Cliffs.

28. Setiawan, H.R.N \& Anasy, M.M. (2008). After New Paradigm Catatan Para Ulama Tentang LDII (Lembaga Dakwah Religion Indonesia). Jakarta: Pusat Studi Religion Madani Institut.

29. Simon, B. \& Taylor, J. (2009) What is the value of course-specific learning goals? Journal of College Science Teaching. Nov/Dec: 53-57.

30. Stanny, C.J. (2016). Reevaluating Bloom's Taxonomy: What Measurable Verbs Can and Cannot Say about Student Learning. Education Sciences, 6(37), 1-12. https://doi.org/10.3390/educsci6040037

31. Sudjana, N. (2002). Dasar-dasar Proses Belajar Mengajar. Bandung: Tarsito.

32. Sugiyono. (2013). Metode Penelitian Pendidikan, Pendekatan Kuantitatif, Kualitatif, dan $R \&$ \&. Bandung: PT. Alfabeta.

33. Ur, P. (2006). A Course in Language Teaching. Practice and Theory. UK: Cambridge University Press.

34. Warschauer, M. (2000). The Changing Global Economy and the Future of English Teaching. TESOL QUARTERLY, 34(3), 511-535. https://doi.org/10.2307/3587741

35. Widdowson, H. G. (2003). Defining Issues in English Language Teaching. Oxford: Oxford University Press. 